\title{
THE REPRESENTATION OF OTTOMAN COURT TEXTILES IN CINEMATOGRAPHIC NARRATIVE: FERZAN ÖZPETEK'S HAREM SUARE
}

\section{Asst.Prof.Dr Tülay GÜMÜȘER *}

\begin{abstract}
Absract: Cinema benefits from design tools in many respects in the creation of both the representation and the reality. Making an interior design with textile design tools is closely related to the expression in cinema. The compatibility of each design object with the location and the content of a movie is important in terms of the fact that they will be presented to the audience. Especially in historical movies, textile objects are expected to reflect the reality. Textile and cinema, which contain different dynamics, are different from the other disciplines in semantic and technical terms. These two disciplines, which have a visual aesthetic in them, continuously improve in the historical process and contribute to the transformation of one another. This study in which the combination of textile and cinema in the creation of an interior design is discussed in design and time together, deals with the place of textile objects in the creation of the interior atmosphere and the movie image. Within the scope of this research, the relationship between textile and cinema has been analyzed through the images, places and characters presented to the audience in the movie Harem Suare
\end{abstract} (1999).

Keywords: Ottoman Court Textiles, Cinema, Interior Textiles, Harem Suare 


\section{OSMANLI SARAY TEKSTILLERININ SINEMATOGRAFIK ANLATIDA TEMSILI: FERZAN ÖZPETEK'IN HAREM SUARE'Si}

\section{Dr.Öğr.Üyesi Tülay GÜMÜȘER*}

Özet: Sinema, temsiliyet ve sinemasal gerçeklik yaratımında birçok açıdan tasarım araçlarından faydalanmaktadır. İç mekan kurgusunun tekstil tasarım araçlarılla tasarlanması ifade bakımından sinema ile yakın ilişkilidir. Tasarlanan her bir nesnenin mekan ve film içeriğiyle uyumlu olması izleyiciye sunabilecekleri önemli detaylardır. Özellikle tarihi filmlerde tekstil nesnelerinin gerçekliği yansıtması beklenir. Farklı dinamikleri içinde barındıran tekstil ve sinema, anlamsal ve teknik bakımdan diğer disiplinlerden ayrışmaktadır. Görsel bir estetiğe sahip olan bu iki disiplin, tarihsel süreçte kendilerini sürekli geliştirirken, bir yandan birbirlerini etkileyerek diğerinin dönüşümüne katkıda bulunurlar. İç mekan kurgusu yaratımında tekstil ve sinema birlikteliğinin tasarım ve zaman düzleminde ele alındığı çalışmada; iç mekan atmosferini yaratmada ve film imgesinin yaratım sürecinde, tekstil nesnelerinin bu imge bütününde kapladığı yer araştııımaktadır. Araştırma kapsamında Harem Suare (1999) filmi üzerinden izleyiciye yansıttığı imgeler bütünü, mekan kurgusu ve karakterler üzerinden tekstil ve sinema ilişkisi analiz edilmiştir.

Anahtar kelimeler: Osmanlı Saray Tekstilleri, Sinema, İç Mekan Tekstiller, Harem Suare

\footnotetext{
* Selçuk Üniversitesi/Mimarlık ve Tasarım Fakültesi/ Konya/Türkiye/ tulaygumuser@gmail.com / ORCID: 0000-0002-6264-2629
} 


\section{INTRODUCTION}

Ottoman Court Textiles, which have a rich variety of motifs in our Turkish textile art, symbolized the economic and political power of the Empire in terms of the materials, weaving techniques, motifs and compositional characteristics. Textiles were used not only for dressing up and protecting oneself from the cold, but they have become the objects of art and design in daily life over time. Creativity in textile design is an indicator of the change and development of a society from past to the present. It is also the textile which is an indispensable element of the interior design. Textile is a field which relates to many other fields such as technology, crafts, social sciences and even economics. Cinema is also one of these fields. The cinema recreates the dominant perception and changes a space into a cinematic space with its own techniques. In the production process, it also benefits from the design tools such as the textiles. In all movie genres, the phenomenon of space is a complementary element presenting the characters in a realistic way while transferring the script and making it felt by the audience. Textile objects are the main elements that determine a certain type of humans, reflecting the common taste of the majority. In short, a space can be called an important and necessary element for cinema because the place in which the movie is shot is just as important as the movie itself. As for the period movies in today's cinema, textiles and costumes sometimes look like the original ones, while sometimes modern interpretations can be made to increase their effect on the audience. The textiles used in the period movies are usually prepared with the inspiration from the past. Therefore, the studies on the relationship of textile design with cinema are gaining importance in producing interdisciplinary knowledge. In the study, the importance of interior textiles in the creation process of a movie image has been analyzed through the movie Harem Suare, which was directed by Ferzan Özpetek. The study focuses only on the interior textiles and their design. The interaction and the relationship between the space and the textiles have been analyzed after revealing the general framework.

\section{METHODOLOGY}

Case study and the qualitative research method have been used in this study. Case studies were among the first types of a research in the field of qualitative methodology (Mills et al. 2010:109). A case study is a story, which is about something unique, special or interesting to the audience and they can be about the individuals, processes, organizations, programs, institutions, neighborhoods and even the events (Robert, 2003). Literature reviews and academic publications (such as academic books, journals, catalogs, web, articles and papers) have been used within the scope of the case study. A descriptive analysis has also been used in this study. The interpretation has been made simultaneously with the analysis. The results of the analysis have been interpreted by the author in terms of the principle and elements of design. The movie Harem Suare, which forms the research population, has been seen more than once. After a detailed analysis, a sequence paper has been prepared for the visual examples. The examples in the study consist of the visuals obtained by a screen shot on the specified sequences. There are 6 visual examples selected according to their different textile designs: Harem Room (figure 1), Sultan's Room (figure 2), Odalisques' Room (figure 3, 4, 6), Odalisque's Bedroom (figure 5). In scenes/sequences where the orientalist themes are predominant, the similarities and differences between the related textile objects and the period have been examined on the axis of time-space and culturevalue. The aim is to examine the patterns, colors, 
motifs and technical features of the textiles that had an important place in the Ottoman period and making them gain a place in the literature through the movie Harem Suare. For this purpose, the following questions have been tried to be answered:

-What are the design features of the patterns and motifs on the textile surface?

-Were the examples of the 19th century textiles in the Ottoman palace within the scope of the movie realistic?

\section{OTTOMAN COURT TEXTILES, CINEMA AND SPACE}

3.1. Ottoman Court textiles (19th century)

The art of textiles has been one of the important elements of our cultural history and daily lives. It has gained an important place in the lives of the communities in different geographical regions. Textile is one of the oldest fields of art in history. Throughout history, each nation has produced its own fabrics of different motifs and materials (felt, wool, cotton, velvet, silk...etc.) in parallel to the cultures, customs, and also the economic levels. Today, Turkish fabrics, velvet and caftans, which have gained fame and appreciation, are usually attributed to the 16th century at the museums around the world. The reason for it is that the fabric sector reached its highest level and the greatest examples were created in the Ottoman Empire in that century. Whereas, the production of the fabrics started before the 16 th century, and in the 16th century it finally reached the highest level. (Gezer, 2012:200). There are some patterns and compositions coming from the interaction between the Ottomans and the Western countries, and there is a western effect on the 19th century textiles. These textiles have the design features that come up as a result of blending the old with the new. Textiles are generally named according to the cities in which the weaving ateliers are located, the number of colors, patterns, field of use and weaving techniques. The examples of the fabrics named after the cities they were weaved in are Aleppo Fabric and Bursa Fabric; after the cities they are used in are Trablus Kuşağı and Konya Sevaisi; after the names of individuals are Haci Ali Bezi, Bakkaloğlu işi and Selimiye. The fabrics are called Velvet (Kadife), Çatma, Kemha, Seraser, Atlas, Canfes and Kutnu according to the techniques used in the production process. The examples of the fabrics named according to the number of colors are Serenk and, Heftrenk, according to the pattern are Gülistanî, Çınarlı and Benekli. (Yetkin, 1993: 332.) The common feature of these fabrics is that they were weaved of raw silk, and some of them were made with gold and silver threads and tinsels (Gümüşer, 2011: IV). When it comes to the weavings of the period, there appears the woolen fabrics, Bursa İpeklisi, Kutnu, Serenk, İpekli Brokar, Çatma, Zerbaft, Seraser, Atlas, Heftrenk, Gülistanl, Çınarlı, Benekli, Canfes, Velvets (Kadife) and Hatayi /Hatai (Akpınarlı and Başaran, 2018: 28-36).

\subsection{Cinema and Space}

Cultural codes are heavily included in cinema in order to gain the appr

eciation of society and to attract people's attention. For this reason, a cinema movie is an element that promotes intercultural communication for different cultures to know and understand each other, and to reduce their prejudices against each other (Mai and Winter, 2006:8). In other words, cinema is a global tool that is the carrier of the cultural characteristics it contains (Çetin Özkan, 2014:342). Globalization has increased the importance of cinema and brought a uniformity orientalist perceptions. The space of the movie is predominantly the harem and the bath. All the textiles and objects there are the space On the one hand, this caused the destruction of locality and one's own being; 
on the other hand, it has spread to the other areas by leaving its own field with such factors as locality and migration. In other words, people who migrate out of their country for economic and social reasons take with them their local characteristics such as traditions and customs. Especially the directors living in different countries reflect their cultural identity in their movies. These movies are usually period movies and have local elements in them. These elements prevent the uniformization in the aforementioned globalized world of cinema.

First of all, the society and culture should be well synthesized and learned in order to tell an opinion or an object in the cinema (Künüçen, 2001:63). "The design tools are used in the cinema, which is an art form and a communication tool for the purpose of constructing the narrative and visuality. Design is affected by cinema in many ways. It finds a new field such as the visual design of posters, costumes, or even web sites which serve for the marketing of the movies. Cinema utilizes the design principles and elements to construct a cinematic world. It takes the advantage of designs for the objects and spaces used in the movies" (Yllmaz, 2009: 55,56). Textile and space, one of the indispensable design tools of the cinema, has always had an organic bond (Doğan, 2019:43). The concept of time is also important in reflecting the period of the movie. It is possible to say that it is the Ottoman period when historical textiles were used the most. Harem Suare is one of the movies describing the Ottoman period, in which the oriental effects reflecting the Eastern atmosphere could also be seen. The movie is interesting in terms of the local elements used by Turkish director Ferzan Özpetek, who lives in Italy, to reflect Eastern and Western culture. These elements are told from the inside of the palace, where there is no contact with the outside. The change of the textiles in the palace in the 19th century is an important detail. The following part explains the textiles in question through the visuals under the themes "interior textiles aimed at giving a realistic effect" and "interior with flashy textile objects".

\section{THE 19th CENTURY OTTOMAN COURT TEXTILES IN HAREM SUARE}

Harem Suare tells the story of the last period of the Ottoman Empire especially in the period of Sultan Abdulhamit II. Time, fictionally and transitionally, navigates between the present and the past. As a result, the palace, the power relations in the palace and the struggle of the odalisques to become the Sultan's favorite are described as the distant past (Yllmazkol, 2008:174). Cultural differences cause the same information to be processed in different ways (Rapaille, 1011:6). Each culture has its own traditions, ceremonial behaviors, symbols and values. Ferzan Özpetek reflects the Mediterranean culture and blends the Turkish tradition with the movies (Çetin Özkan, 2014:343). The paintings by the orientalist painters reflecting the East contributes to the visual narrative of the movie Harem Suare (Yllmazkol, 2008:178). The orientalist painters in question are Gerome, Trouillebert, Lewis and Panson. Among the works that describe the harem and the bath in the harem are Gerome's The Great Bath and The Bath, Trouillbert's Harem Servant Girl, Lewis's The Siesta, and Panson's The Message, which reflect the mysterious look of the Western people (Uluç and Soydan, 2007: 43,44). It is seen that Özpetek's desire to give action to his thoughts on the East is reflected in the language of an image (Arnheim, 2002:138). Harem Suare brings its own formal features to the historical period. This is shaped by the retrospective organizers (Kıliç, 1994:26), namely the design tools organizing the space. These are peshtamals, kerchiefs, embroideries, towels (peşkir), curtains,napkins 
„ laces and braids. These textiles provide clues about the lifestyles and the identities of the community. The textile objects used in Harem Suare draw the image of the Ottoman period and coincide with the design tools in terms of the way of telling. Fabrics used in the interior textiles come to the forefront with their functional colors and pattern designs in general.

In the first example, one of the first scenes of the movie, which includes the rituals of the Ottoman Empire, there is a large carpet in the center of the Harem room (fig. 1). The influence of the Uşak carpets in the 16th century, when the Ottoman palace carpets reached the highest level, is not seen in the 19th century. In the 19th century, there are plant motifs such as penç leaves, hatayi and semi-styled flowers, which are in the hatai group. Rumi motif and several types of it also stand out in this period. These carpets, where the colors of blue and red were at the forefront, were hand-woven and they were unique for the palace.

The ground of the carpet in the movie is red, one of the dominant colors of the 19th century. The surface design of the carpet consists of the plant motifs placed in a free order. There is a repeat system for the same motifs at the bordure. The edges of the carpet are framed with a fine red bordure. Cream, light green and earth toned colors were also used in a limited amount for the patterns and motifs. It is possible to say that the design elements such as colors, but repeat system, action, rhythm, lines, forms and orders were used in the composition of the carpet.

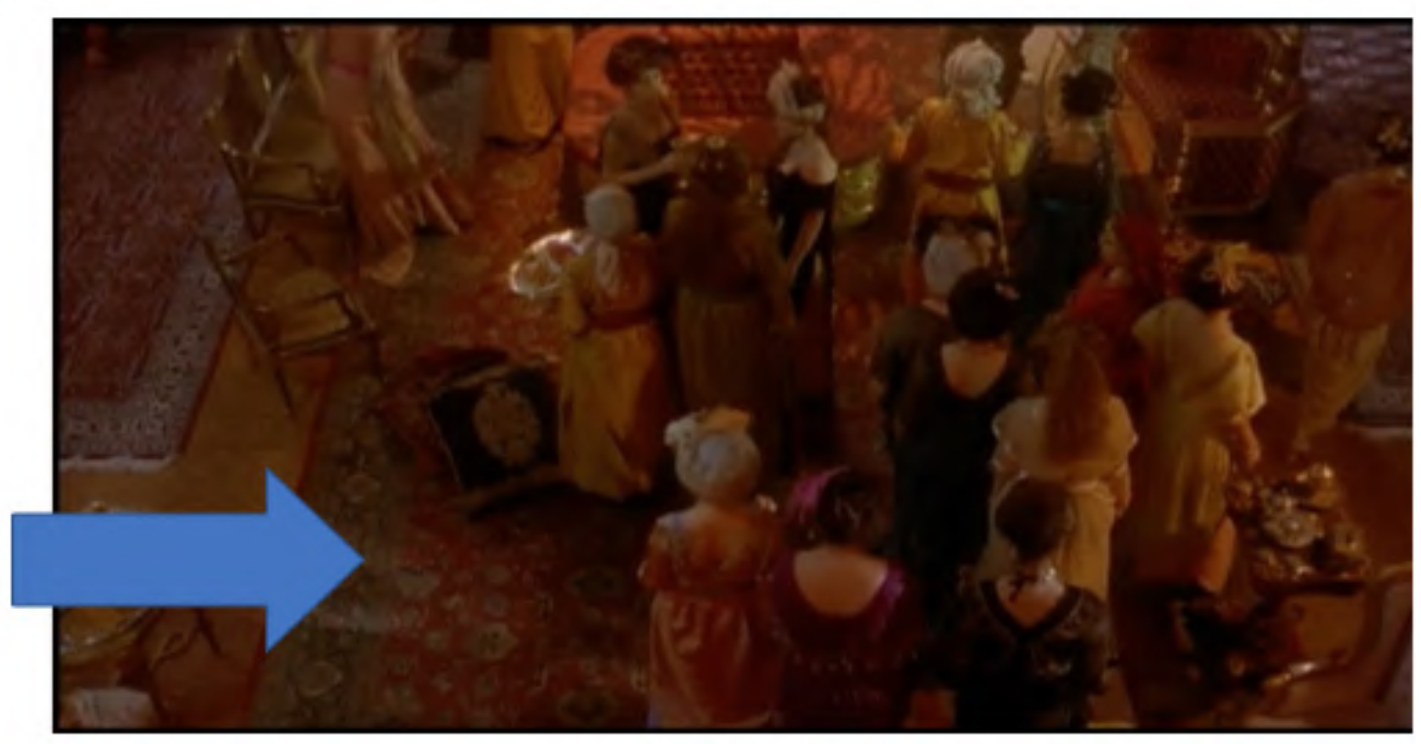

Figure 1: Harem Suare. 1999. 1h.50m. Harem Room. Source: Screenshot by author in 2020

Identities and ethnic background presented or obtained/gained within the shared living spaces do not give a superiority or an interiority to the movies directed by Özpetek. On the contrary, such differences are depicted as intermediate formations that give color to the life (Yllmazkol, 2008:239). The movie offers a comparative reading about the places, forms and oppositions, in which space is represented along with time (Z. Tül Akbal, 283). Harem Suare is a formation which has a highly-stylized, fable-like narrative and visuals; however, the truth-telling narration is still disguised and complicated (Engin, 2004:121). The movie draws attention to three things in the Ottoman harems in the 1900s: love, power and fear. 
This reflects what the West thinks about the East. Love, which is one of the concepts the West uses in its depiction of the East, reflects a mystical and mysterious image for the East (Şirin, 2019:106). The use of red color mainly on the interior textiles and costumes in the movie supports the aforementioned depiction of love, power and the East.

In the other example, the red color is seen to be predominantly used for such interior textiles as the curtain and the seat upholstery, and for the actor's caftan (Haluk Bilginer), who represents the Sultan (fig. 2). Tulips, cloves, penç, hatayi, rumi, roses, arborvitae motifs and medallion motifs, which were frequently used in the 16th century, leave their place to the flowers in the vases, the bunch of flowers with thin branches and leaves and the plant motifs in the 19th century. These are more arranged in a geometric order (Kavc1 Özdemir, 2006:307-312). As seen in the example, the repeated geometric motifs used in the composition of the fabrics in the palace confirm the change in this period. Textile surfaces consist of design elements such as colors, forms and lines. The small geometric motifs seen on the screen are in a full repeat system and embroidered with golden-colored threads. In the composition of the pattern on the Sultan's clothing, the use of curved leaves and branches shows a European effect. Color, which is one of the indispensable elements of design, is given here in two different types (red and golden yellow). The selection of colors to be used in cinema depends on various reasons:

1- Physical reasons; colors can affect the audience by giving them a more or less pleasing feeling

2- Psychological reasons; colors can stimulate people's psychological responses

3- Aesthetic reasons; colors can be selected according to the effects that they will make, considering the composition, proportion and balance within the movie (Braga and Costa, 2011:333).

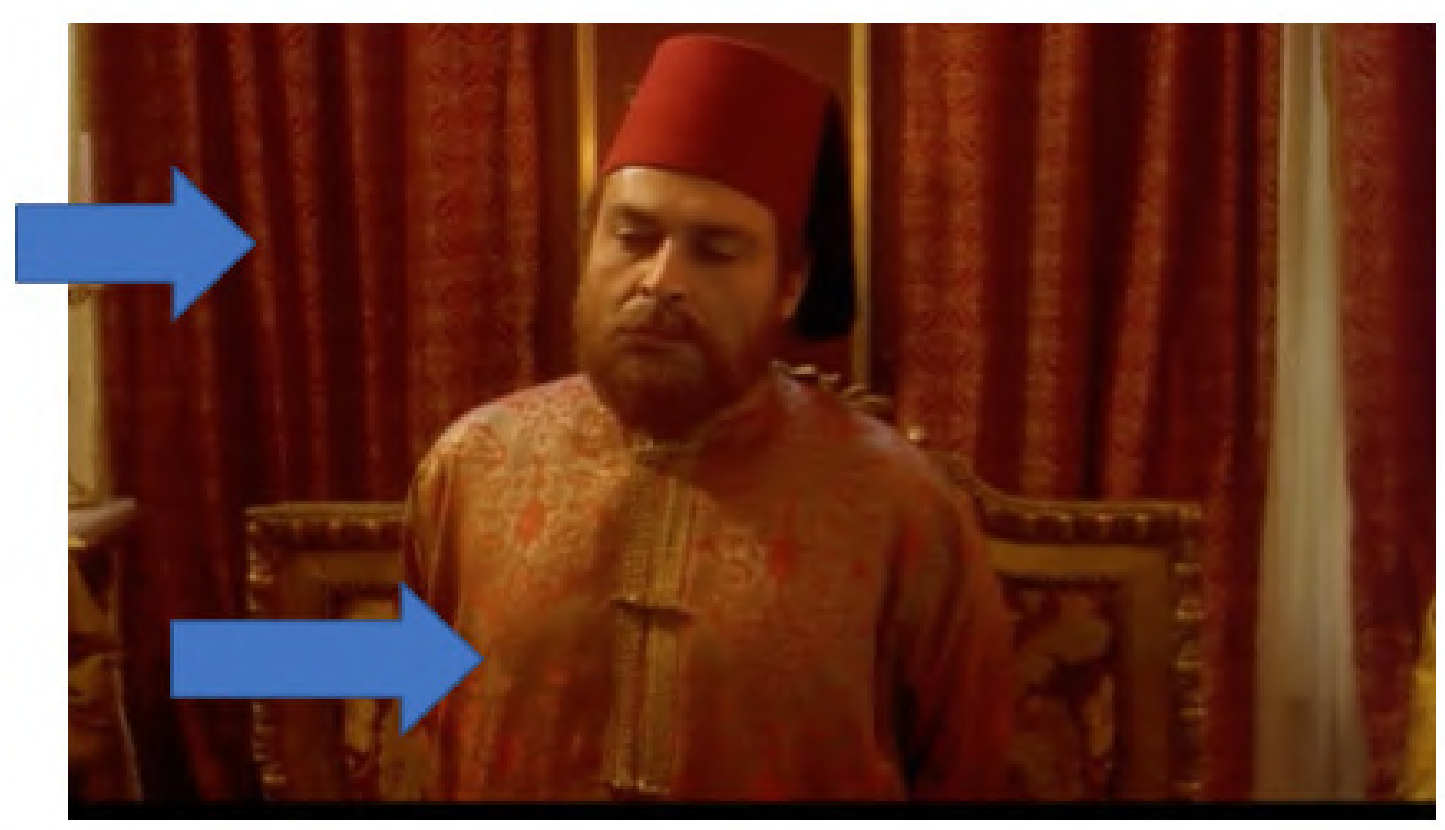

Figure 2: Harem Suare. 1999. 1h.50m. Sultan's Room. Source: Screenshot by author in 27.03.2020 


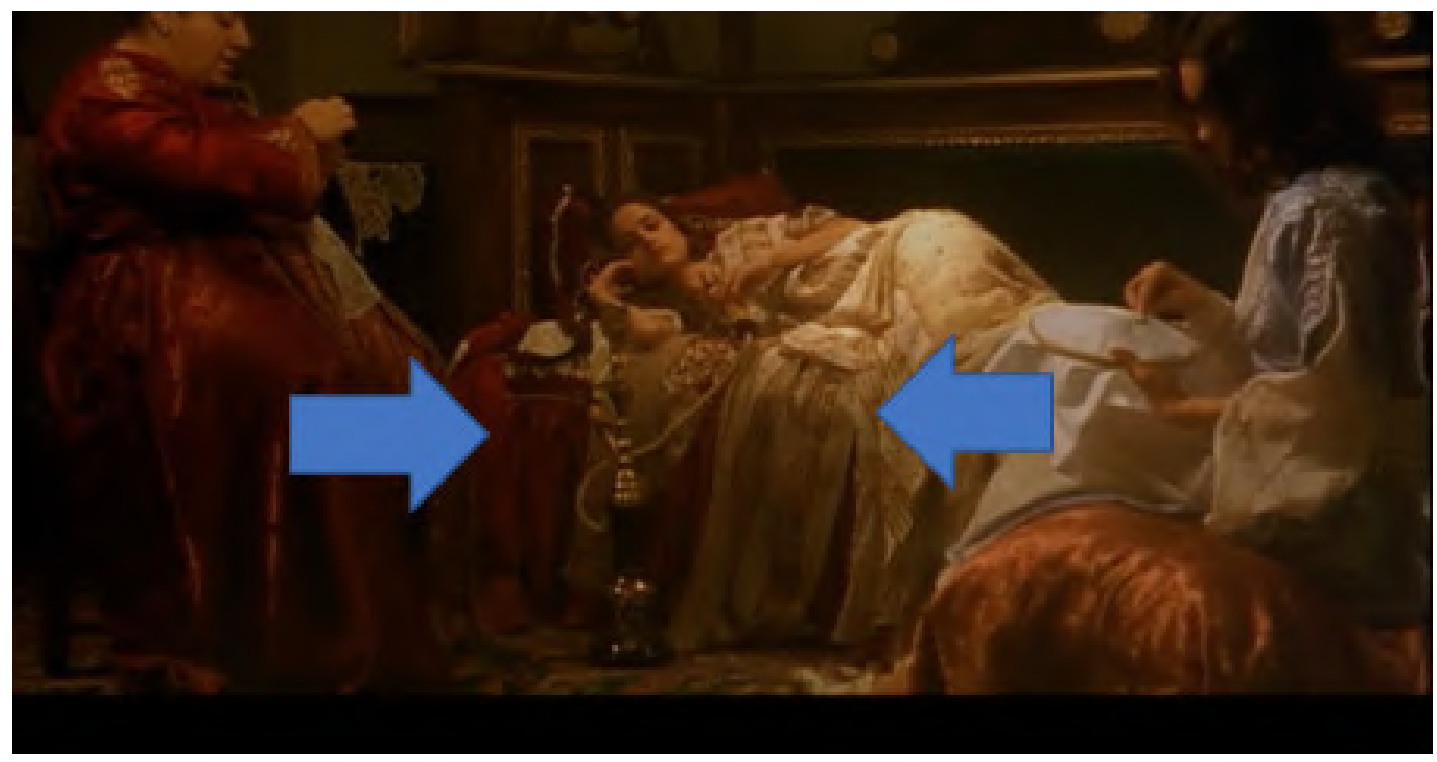

Figure 3: Harem Suare. 1999. 1h.50m. Handmaiden's (Safiye) Room. Source: Screenshot by author in 27.03.2020

Both colors are symbolic colors used at most in the classical period. The importance of meaning content of the red in the material production of Turks is understood from its frequent usage. The caftan and tabard in red color (al) became the symbol of Turks (Ögel, 1991:401-403). This color which symbolizes the power of the Ottoman rule, must have been preferred to reflect the power and love in the triangle of power, love and fear in the film Harem Suare. Correspondingly, using the yellow color with red may be related to the symbolic meanings because it has the meanings of power, strength and sovereignty in Turkish culture (Genç, 1997: 31). Considering the clothes which are the indicators of Ottoman wealth, it is not a coincidence for the red fabrics to be weaved with gold threads.

Lace, kerchief, towel, cover, handkerchief, pillowcase, and embroidered textile objects were one of the engagements of women. The textiles that women do by coming together in their free times were quite demanding. These handicrafts were often shown in Harem Suare in reflecting the women of the time. For example, in a scene in where there were three women, one character was embroidering with her hand (on the left), while another one was embroidering on a hoop (on the right). The handmaiden (Safiye) on which a red satin cover and embroidered pillow slip are located was smoking hookah /water pipe while lying on a sofa. Satin fabrics are seen on all of the fabrics. Shining satin fabrics reflecting the glory of the period confronts us sometimes as plain and sometimes as embroidered fabrics (fig. 3).

The cloth of the character on the left is made of plain satin fabric in red and has some Rumi motifs on it, which were made with golden threads. The kerchief on the sofa where the Odalisque is lying is red and has plant motifs made with golden yellow threads. The odalisques's cloth is made of cream tones with vertical striped patterns at the edges. When looking at the design, the elements consisting of lines, forms, colors and repeats attract the attention. Baroque and rococo styles of the time and neo-classical style, which appeared later, started to show their effects on court fabrics (Yilmaz and Sipahioğlu, 2006: 216,217). 
The textiles in integrity with the objects and performers in film's indoor are encountered at every corner of the court. As a classic design and composition elements of Ottomans were encountered in the indoor setting, baroque and rococo styles were more dominant in the interior design, besides the classical patterns and composition elements of the Ottoman Empire. Rococo-style plant patterns consist of the sliced leaves on the branches, $\mathrm{C}$ and $\mathrm{S}$ shapes, spirals, vases with the traces of Neo-classical style, drapes, boats, human figures and geometric arrangements (Yilmaz and Boynak, 27,28). Especially the bundles and plant motifs, which are made up of thin branches and leaves, appear in a form placed in a geometric arrangement.

Another example of this style is seen in the pattern on the blue fabric of the Odalisque's cloth (fig. 4). There is a freestyle of the thin branches and small flowers in the pattern design of the cloth. There are such design elements as rhythm, action and balance in the technical composition of the patterns. A triangular wall cover, which is unique to this period full of embroidery was also placed above the sofa in the same frame. The sofa kerchief is made of red satin fabric with

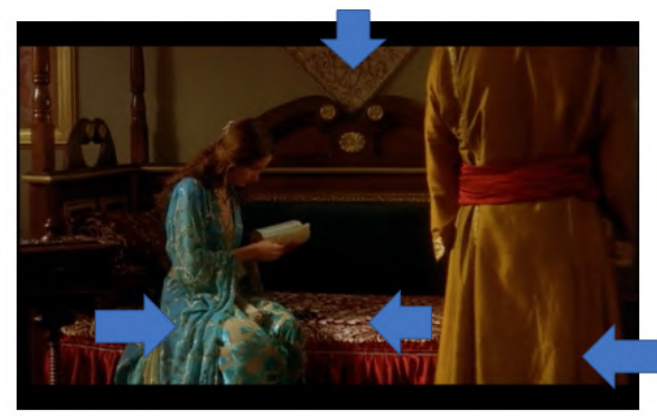

Figure 4: Harem Suare. 1999. 1h.50m. Handmaiden's (Safiye) Room. Source: Screenshot by author in 27.03 .2020 frills and decorated with cream-colored plant motifs. The eunuch (on the right) wears a cloth made of golden plain fabric and a red belt around his waist. This fabric is similar to Kutnu (Kutni), which was frequently used during the Ottoman period. The arms and collar of the cloth are also embroidered with delicate yellow striped motifs. The textiles seen here match with the examples of the ordinary people's textiles rather than the court members in the Ottoman Palace.

When it comes to the Turkish tradition, the quilts made of silk fabric come to mind. These quilts with traditional motifs are indispensable textiles of everyday life. Quilts, which are used for covering or protecting from the cold, is a cultural product because it is one of the most commonly used objects in our life and there is at least one in every house (Al, 2005:34). Quilts, one of the handicrafts reflecting the traditional kindness and elegance in Turkish Culture, is a cultural material showing the public's aesthetics (Duvarc1, 2007:507). The director used the traditional tools while reflecting the odalisques sleeping together in the harem on the screen. The principle of one color in traditional quilts is highlighted here with the color of pink (fig. 5).

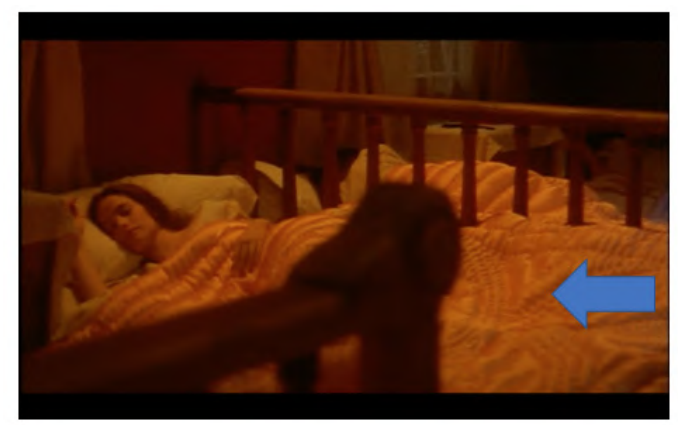

Figure 5: Harem Suare. 1999. 1h.50m. Handmaiden's Bedroom. Source: Screenshot by author in 27.03 .2020 


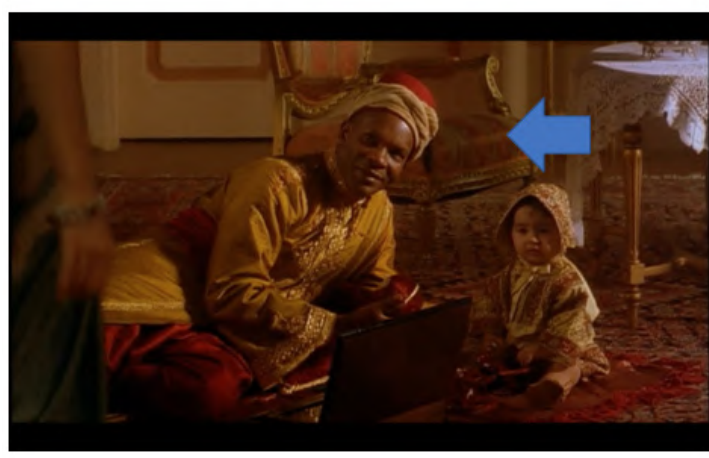

Weaving the fabrics in the jacquard looms, coming from Europe during the Ottoman period, are in the same line with the techniques and technology used in the European countries. These fabrics have floral patterns and Kutnu-like stripes with the spirals between them (Tezcan, 2006:408). In the last example, it is seen that this type of a fabric was also used in the clothing of a chair (fig. 6). There are floral motifs on the stripes used in the upholstery fabric's surface design which consists of vertical stripes of pink and green side by side. This chair is an example of the interaction between the East and the West. While the classical understanding of pattern in the Ottoman Empire can be seen here, some motifs on the silk fabrics have a common feature with the Italian fabrics' patterns. This interaction may be due to the fabric trade between the Italians and the Ottomans. Since the machines were used to produce larger patterned and multi-coloured fabrics for the first time in the 19th century, it is not wrong to say that most of the fabrics in Harem Suare are machine-made. There is no doubt that the fabrics and pattern designs were created according to different likes in parallel with the changing social structure.

\section{CONCLUSION}

In this study, in which the 19th century textiles used in the Ottoman Palace's interior designs have been discussed through a movie, stereotyped and desirable representations of the East are often
Figure 6: Harem Suare. 1999. 1h.50m. Handmaiden's (Safiye) Room. Source: Screenshot by author in 27.03.2020

emphasized from a Western point of view. Ferzan Özpetek has been affected by the change in the global and local contexts and his original views. With this effect, he used the themes reflecting the Western assessment of the East. The textiles that we see at almost everywhere of the palace undoubtedly have a significant effect on this representation. Both places, Turkish baths and harems, are related to privacy, and they also have some erotic connotations. Oriental spaces also have some forms of social relationships in them. Therefore, each textile object was consciously designed and reflected to the audience in connection with this social relationship. The perception of time, defined as an indicator of the change and transformation between space, matter, and energy, is on a line from the past to Western Europe's. As for the textiles used in the interior design of Harem Suare, it is possible to say in general that they are selected according to the structural terms and the pattern features. All the interior textiles used in the movie have a functional aspect rather than a visual one in many stages.

When examined with the perspective of design, it is observed that the elements used on the textile surfaces are the lines, colors, forms, orders (figure $1,2,3,6$ ); repeats (figure 1, 2, 3, 4, 6); and action and rhythm (figure 1). As for the color selection, it is seen that the colors used in the textile design are red (figure 1,2, 3), yellow (figure 1, 2, 4, 6), earth tone (figure 1), light green (figure 1, 6) 
, pink (figure 5, 6), and blue (figure 4). The things that all the textiles have in common is the silk-satin woven fabrics. The colors of the pink and earth tones are those that represent the 19th century while the colours of red, yellow, blue and green belong to the classical period (the 16th century). The colors and silk fabrics which symbolize power, grandeur, wealth and status in the classical period may have been consciously preferred in the movie. Whereas, the colors in the 19th century may have been used to reflect the reality of the period. It is observed that there are curvy leaves and branches, and small flowers used in some of the textiles. C and S curved leaves in Rococo-style are dominant among the plant motifs. In one example, there is also the Rumi motifs seen to be preferred (figure 3). The explanations above answer the first question of this study: What are the design features of the patterns and motifs on the textile surface. As for the second question: Were the examples of the 19th century textiles in the Ottoman palace within the scope of the movie realistic? It is possible to say that the Westernization effect is felt on every scene and selected examples of the movie, representing the 19th century Ottoman Palace. The flashy fabrics of the objects such as thrones, armchairs and sofas, and such interior textiles aimed at reflecting reality as quilts, peshkirs, coverings and kerchiefs represent the Ottoman period. 


\section{REFERENCES}

- $\quad$ Akbal Süalp T. Z. (2004.) Zamanmekan. İstanbul: Bağlam Yayınları

- Al, M. 2005. Iğdır'da Yorgancılık. (2004) Yılında Türkiye’de Yaşayan Geleneksel Meslekler. Gazi Üniversitesi. Ankara: THB Merkezi Yayinlari.

- Braga, H. M. and Costa V. (2011). Color in Films: A Critical Overview. Critica Cultural. Vol.6 No.1

- Doğan, T. (2019). Tekstil Tasarımın İç Mekanda Kullanımının İncelenmesi. Haliç Üniversitesi. Lisansüstü Eğitim Enstitüsü. Yayınlanmamış Yüksek Lisans Tezi

- Duvarcı, A. (2007). Kaybolan Bir Kültür Yorgan ve Yorgancılık. Halk Bilimsel Yaklaşım. ICANAS, No.2 S. 2 S. 507-516

- Engin, E. (2004.) Figuring the Orient: A Discussion of Orientalism within the context of Ferzan Özpetek's Films. Bilkent University, Institute of Fine Arts. Unpublished Masters Thesis

- Genç, R. (1997). Türk İnanışları ile Milli Geleneklerinde Renkler. Ankara: Atatürk Kültür Merkezi Yayınevi.

- Künüçen, H. and Ateş, N.H. 2001. Fatih Akını̀n Filmlerinde Kadının Sunum Biçimi.

- $\quad$ Ögel, B. (1991). Türk Kültür Tarihine Giriş. I-IX, Ankara: Kültür Bakanlı̆̆ı Yayınları.

- $\quad$ Özdemir Kavcı, E. (2006). 19. Yüzyıl Batı Tarzı Süslemelerin Osmanlı Döneminde Bir Grup Kumaşa Yansıması. 10. Ulusal El Sanatları Sempozyumu, İzmir. 16-18 Kasım. S. 307-312

- $\quad$ Özkan Çetin, Z. (2014). Kültürlerarası Etkileşimde Sinemanın Rolü: Ferzan Özpetek ve Fatih Akın Filmlerinde Kültürlerarasilik. International Journal of Science Culture and Sport. Special Issue on the Proceedings of the 3rd ISCS Conference. S. 1 P.340-349 Doi: 10.14486/IJSC101.

- Rapaille, C. (2011). Kültür Kodu. İstanbul: FGD Yayıncılık

- S Şirin, Y. (2019). Oryantalizm Bağlamında Ferzan Özpetek Sineması. Maltepe Üniversitesi. Sosyal Bilimler Enstitüsü. Yayınlanmamış Yüksek Lisans Tezi.

- Tezcan, H. (2006). Osmanlı Sarayının Çocukları (Şehzade Hanım Sultanlarının Yaşamları ve Giyimleri). İkinci Basım. MAS Matbaacılık A.Ş. 302s.

- $\quad$ Yılmazkol, Ö. (2008). Kültürlerarası İletişim ve Etkileşim Sürecinde Ferzan Özpetek Sineması: Benzerlikler Farklılıklar ve Melezlikler. Ege Üniversitesi. Sosyal Bilimler Enstitüsü. Radyo Televizyon Anabilim Dall. Yayınlanmamış Doktora Tezi.

- $\quad$ Yilmaz, Y. and Boynak, S. (1999). Hereke Fabrika-i Hümayunu ve İpekli Jakar Dokumaları. Milli Saraylar Koleksiyonunda Hereke Dokumaları ve Halıları. TBMM Daire Başkanlı̆̆ı Yayını. İstanbul. S. 22-37

- Yilmaz, T. (2009). İstanbul, Not Constantinople: The use of Designerly Tools in the Representation of Istanbul in American Cinema. The Izmir University of Economics. The Graduate School of Social Sciences. Unpublished Master Thesis.

- Yılmaz, N. and Sipahioğlu, O. (2006). Dolmabahçe Sarayında Bulunan Döșemelik Kumaş Desenlerinde Dönemin Sanat Akımlarının Etkisi. 150. Yılında Dolmabahçe Sarayı Uluslararası Sempozyumu. İstanbul, 23-26 Kasım. S.216,217 